\title{
PEMANFAATAN KULIT RAMBUTAN SEBAGAI BOKASHI UNTUK \\ MENINGKATKAN PERTUMBUHAN DAN HASIL BAYAM CABUT (Amaranthus tricolor, L)
}

\author{
Herlina Kurniawati \\ Fakultas Pertanian Universitas Kapuas Sintang \\ email: herlina_kurniawati@yahoo.com
}

\begin{abstract}
Abstrak: Bayam merupakan salah satu jenis sayuran hijau yang banyak manfaat bagi kesehatan. Bayam banyak memiliki kandungan berupa vitamin dan meneral, seperti vitamin $\mathrm{A}, \mathrm{B}$, dan $\mathrm{C}$, protein, kalsium dan zat besi yang dibutuhkan oleh tubuh manusia. Penelitian ini bertujuan untuk mengetahui pengaruh pemberian bokashi kulit rambutan terhadap pertumbuhan dan hasil bayam cabut dan dosis bokashi kulit rambutan yang memberikan hasil tertinggi. Penelitian ini dilakukan dengan metode percobaan lapangan. Rancangan percobaan yang digunakan adalah Rancangan Acak Kelompok dengan bokashi kulit rambutan sebagai perlakuan yang terdiri dari lima taraf dan lima ulangan yaitu : tidak diberi bokashi kulit rambutan $\left(\mathrm{N}_{\mathrm{O}}\right), 0,5 \mathrm{~kg}$ bokashi kulit rambutan $\left(\mathrm{N}_{1}\right), 1 \mathrm{~kg}$ bokashi kulit rambutan $\left(\mathrm{N}_{2}\right), 1,5 \mathrm{~kg}$ bokashi kulit rambutan $\left(\mathrm{N}_{3}\right)$ dan $2 \mathrm{~kg}$ bokashi kulit rambutan $\left(\mathrm{N}_{4}\right)$. Hasil penelitian diketahui bokashi kulit rambutan berpengaruh terhadap pertumbuhan dan hasil bayam cabut pada tanah PMK, yang ditandai tinggi tanaman dan berat segar tanaman. Pemberian $2 \mathrm{~kg}$ bokashi kulit rambutan menghasilkan tinggi tanaman dan berat segar tanaman tertinggi dengan rata-rata $23,40 \mathrm{~cm}$ dan 77,50 gram pertanaman.
\end{abstract}

Kata Kunci : Kulit rambutan, bokashi, pertumbuhan, hasil, bayam cabut

\section{PENDAHULUAN}

Bayam (Amaranthus tricolor

L) merupakan salah satu jenis sayuran hijau yang banyak manfaat bagi kesehatan. Bayam banyak memiliki kandungan berupa vitamin dan meneral, seperti vitamin $A, B$, dan $\mathrm{C}$, protein, kalsium dan zat besi yang dibutuhkan oleh tubuh manusia. Bayam juga berfungsi untuk mencegah penyakit anemia atau kurang darah, sakit kuning, memperkuat tulang, meluruhkan PIPER No.27 Volume 14 Oktober 2018 kencing (diuretik) pada penyakit kencing nanah, menghilangkan racun (autitoksid) menyembuhkan bengkak atau luka, obat diare dan membersihkan darah. (Bandini, Y dan Azis, N, 2005:3).

Tanaman bayam cabut merupakan tanaman yang mudah untuk dibudidayakan karena tanaman bayam tidak memiliki syarat tumbuh tertentu dan bisa tumbuh dimana pun dengan berbagai macam kondisi dan jenis tanah. Bayam bisa ditanam 
sepanjang tahun (tidak mengenal musim) dan yang lebih penting tanaman bayam memerlukan sinar matahari penuh. Untuk mendapatkan hasil yang optimal tanah harus banyak mengandung bahan organik dan unsur hara.

Pada umumnya kulit rambutan tidak dimanfaatkan oleh masyarakat, kulit rambutan tersebut hanya menjadi sampah rumah tangga. Padahal dari bahan organik seperti kulit rambutan tersebut bisa digunakan untuk pembuatan bokashi yang banyak memiliki unsur hara dan bisa dijadikan sebagai pengganti pupuk dasar untuk pertumbuhan sayuran bayam cabut.

Bahan organik seperti bokashi kulit rambutan jika dimanfaatkan akan memberikan pengaruh positif bagi tanah karena bokashi kulit rambutan mengandung unsur hara sebagai berikut : $\mathrm{N}$ 0,32\%, P 551,11 ppm, K 7,14 $\mathrm{CMol} / \mathrm{Kg}$ dan $\mathrm{pH} 7,45 \mathrm{H}_{2} \mathrm{O}$.

Tujuan dalam penelitian ini adalah untuk mengetahui pengaruh bokashi kulit rambutan terhadap pertumbuhan dan hasil tanaman bayam cabut; untuk mengetahui dosis bokashi kulit rambutan yang akan menghasilkan pertumbuhan dan hasil bayam cabut tertinggi.

\section{METODOLOGI PENELITIAN}

\section{Metode Penelitian}

$\begin{array}{crr} & \text { Penelitian ini } & \text { dilakukan } \\ \text { dengan } & \text { metode } & \text { eksperimen }\end{array}$
lapangan, menggunakan pola Rancangan Acak Kelompok (RAK). Faktor perlakuan dalam penelitian ini adalah bokashi kulit rambutan yang terdiri dari 5 taraf perlakuan dengan 5 kali pengulangan. Lima taraf perlakuan yang dimaksud sebagai berikut: $\mathrm{N}_{0}=$ Tanpa Bokashi Kulit Rambutan, $\mathrm{N}_{1}=0,5 \mathrm{~kg}$ Bokashi Kulit Rambutan $/ \mathrm{m}^{2}, \quad \mathrm{~N}_{2}=1 \mathrm{~kg}$ Bokashi Kulit Rambutan $/ \mathrm{m}^{2}, \mathrm{~N}_{3}=$ 1,5 kg Bokashi Kulit Rambutan/m², $\mathrm{N}_{4}=2 \mathrm{~kg}$ Bokashi Kulit Rambutan $/ \mathrm{m}^{2}$

$$
\text { Jumlah }
$$

keseluruhan pengamatan adalah 5 taraf perlakuan x 5 ulangan x 16 tanaman dalam tiap petak percobaan $=400$ tanaman. Dalam tiap petak percobaan diambil 4 tanaman x 6 taraf perlakuan $\times 5$ ulangan $=100$ tanaman. 
Pemanfaatan Kulit Rambutan Sebagai Bokashi Untuk Meningkatkan Pertumbuhan Dan Hasil Bayam Cabut (Amaranthus Tricolor, L)

\section{Bahan dan Alat Penelitian}

Bahan-bahan yang digunakan dalam penelitian ini adalah: benih bayam, kulit rambutan, kotoran sapi, air bersih, EM4 200 ml, larutan gula, pestisida tembakau. Alat-alat yang digunakan dalam penelitian ini adalah sebagai berikut: parang, cangkul, drum atau tong plastik, gergaji, kayu tugal, triplek, gunting, timbangan, ember, gembor, mini sprayer, meteran, kamera, alat tulis menulis.

\section{Waktu dan tempat penelitian}

Penelitian ini dilaksanakan pada bulan Juli 2018 sampai
September 2018. Tempat pelaksanaan penelitian adalah di Desa Baning Kota Kecamatan Sintang Kabupaten Sintang.

\section{HASIL DAN PEMBAHASAN}

\section{Hasil Penelitian}

Tinggi Tanaman

Rerata hasil pengamatan pengaruh pemberian bokashi kulit rambutan terhadap tinggi tanaman diperlihatkan dalam Tabel 1.

Tabel 1. Rerata tinggi tanaman $(\mathrm{cm})$

\begin{tabular}{cccccccc}
\hline \multirow{2}{*}{ Perlakuan } & \multicolumn{7}{c}{ Ulangan } \\
\cline { 2 - 6 } & I & II & III & IV & V & \multirow{2}{*}{ Jumlah } & \multirow{2}{*}{ Rerata } \\
\hline $\mathbf{N}_{\mathbf{0}}$ & 15,50 & 17,75 & 18,00 & 12,75 & 11,25 & 75,25 & 15,05 \\
$\mathbf{N}_{\mathbf{1}}$ & 16,00 & 18,25 & 16,50 & 17,25 & 17,50 & 85,50 & 17,10 \\
$\mathbf{N}_{\mathbf{2}}$ & 17,75 & 19,25 & 19,50 & 20,50 & 20,00 & 97,00 & 19,40 \\
$\mathbf{N}_{\mathbf{3}}$ & 19,75 & 21,25 & 21,75 & 22,50 & 22,25 & 107,50 & 21,50 \\
$\mathbf{N}_{\mathbf{4}}$ & 21,25 & 23,25 & 24,00 & 23,76 & 24,75 & 117,00 & 23,40 \\
\hline Total & $\mathbf{9 0 , 2 5}$ & $\mathbf{9 9 , 7 5}$ & $\mathbf{9 9 , 7}$ & $\mathbf{9 6 , 7 5}$ & $\mathbf{9 5 , 7 5}$ & $\mathbf{4 8 2 , 2 5}$ & $\mathbf{1 9 , 2 9}$ \\
\hline
\end{tabular}

Sumber: Pengamatan lapangan, 2018.

Hasil pengamatan rerata pemberian $2 \mathrm{~kg}$ bokashi kulit tinggi tanaman dalam Tabel 1 rambutan $\left(\mathrm{N}_{2}\right)$, rerata tinggi tanaman diperoleh nilai tinggi tanaman terendah pada tanaman kontrol $\left(\mathrm{N}_{0}\right)$ tertinggi yaitu $23,40 \mathrm{~cm}$ pada dengan tinggi rata-rata $15,05 \mathrm{~cm}$. 
Tabel 2. Analisis ragam tinggi tanaman

\begin{tabular}{lcccccc}
\hline \multirow{2}{*}{ SK } & \multirow{2}{*}{ DB } & \multirow{2}{*}{ JK } & \multirow{2}{*}{ KT } & \multirow{2}{*}{ Fhitung } & \multicolumn{2}{c}{ Ftabel } \\
\cline { 6 - 7 } & & & & & $\mathbf{0 , 0 5}$ & $\mathbf{0 , 0 1}$ \\
Ulangan & 4 & 12,16 & 3,04 & $1,13^{\text {tn }}$ & 3,01 & 4,77 \\
Perlakuan & 4 & 222,81 & 55,70 & $20,79^{* *}$ & 3,01 & 4,77 \\
Galat & 16 & 42,86 & 2,68 & & & \\
\hline Total & $\mathbf{2 4}$ & $\mathbf{2 7 7 , 8 3}$ & \multicolumn{3}{c}{ kk $=\mathbf{8 , 4 9 \%}$} \\
\hline
\end{tabular}

Sumber: Analisa data, 2018.

Keterangan: tn = pengaruh tidak nyata pada selang kepercayaan $95 \%$ $* *$ = pengaruh nyata pada selang kepercayaan $99 \%$

$\begin{array}{llll}\text { Hasil analisis data seperti } & \text { tanaman. Langkah selanjutnya } \\ \text { pada Tabel } 2 \text { diketahui bahwa } & \text { dilakukan uji BNJ yang hasil } \\ \text { perlakuan Bokashi Kulit Rambutan } & \text { perhitungannya ditampilkan dalam } \\ \text { berpengaruh nyata terhadap tinggi } & \text { Tabel 3. }\end{array}$

Tabel 3. Uji BNJ Bokashi Kulit Rambutan Terhadap Tinggi Tanaman

\begin{tabular}{|c|c|c|c|c|c|}
\hline \multirow{2}{*}{$\frac{\text { Perlakuan }}{\mathrm{N}_{0}}$} & \multirow{2}{*}{$\begin{array}{l}\text { Rerata } \\
15,05 \mathrm{a}\end{array}$} & \multicolumn{3}{|c|}{ Selisih } & \\
\hline & & - & & \\
\hline $\mathbf{N}_{1}$ & $17,10 \mathrm{~b}$ & $2,05^{* *}$ & \multicolumn{2}{|l|}{-} & \\
\hline $\mathbf{N}_{2}$ & $19,40 \mathrm{c}$ & $4,35^{* *}$ & $2,30^{\text {** }}$ & \multicolumn{2}{|l|}{ - } \\
\hline $\mathbf{N}_{3}$ & $21,50 \mathrm{~d}$ & $6,45^{* *}$ & $4,40^{* *}$ & $2,10^{* *}$ & - \\
\hline $\mathbf{N}_{4}$ & $23,40 \mathrm{e}$ & $8,35^{\text {** }}$ & $6,30^{* *}$ & $4,00^{* *}$ & $1,90^{* *}$ \\
\hline \multicolumn{6}{|c|}{$\mathrm{SE}=0,33$} \\
\hline \multicolumn{2}{|c|}{$\begin{array}{l}\mathbf{Q}_{0,05}=\mathbf{4 , 0 5} \\
\mathbf{Q}_{0,01}=\mathbf{5 , 1 9}\end{array}$} & \multicolumn{3}{|c|}{$\begin{array}{l}\mathbf{B N J}_{0,05}=1,33 \\
\mathbf{B N J}_{0,01}=1,70\end{array}$} & \\
\hline
\end{tabular}

Sumber: analisa data, 2018.

Keterangan: $* *=$ pengaruh nyata pada selang kepercayaan $99 \%$

Hasil uji BNJ menampilkan nilai beda tinggi tanaman bayam yang tertinggi pada perlakuan N4, pada hasil perhitungannya diketahui bahwa tinggi tanaman mengikuti taraf pemberian bokashi kulit rambutan.
Berat Segar

Hasil rerata pengamatan pemberian Bokashi Kulit Rambutan Terhadap berat segar tanaman bayam cabut ditanpilkan dalam Tabel 4. 
Pemanfaatan Kulit Rambutan Sebagai Bokashi Untuk Meningkatkan Pertumbuhan Dan Hasil Bayam Cabut (Amaranthus Tricolor, L)

Tabel 4. Rerata berat segar $(\mathrm{g})$

\begin{tabular}{cccccccc}
\hline \multirow{2}{*}{ Perlakuan } & \multicolumn{7}{c}{ Ulangan } \\
\cline { 2 - 6 } & I & II & III & IV & V & \multirow{2}{*}{ Jumlah } & \multirow{2}{*}{ Rerata } \\
\hline $\mathbf{N}_{\mathbf{0}}$ & 45,00 & 40,00 & 41,25 & 42,50 & 42,50 & 211,25 & 42,25 \\
$\mathbf{N}_{\mathbf{1}}$ & 50,00 & 50,00 & 47,50 & 50,00 & 50,00 & 247,50 & 49,50 \\
$\mathbf{N}_{\mathbf{2}}$ & 57,50 & 52,50 & 52,50 & 52,50 & 60,00 & 275,00 & 55,00 \\
$\mathbf{N}_{\mathbf{3}}$ & 62,50 & 72,50 & 72,50 & 65,00 & 70,00 & 332,50 & 66,50 \\
$\mathbf{N}_{\mathbf{4}}$ & 75,00 & 77,50 & 77,50 & 75,00 & 72,50 & 387,50 & 77,50 \\
\hline Total & $\mathbf{2 9 0 , 0 0}$ & $\mathbf{2 9 1 , 2 5}$ & $\mathbf{2 9 1 , 2 5}$ & $\mathbf{2 8 5 , 0 0}$ & $\mathbf{2 9 5 , 0 0}$ & $\mathbf{1 4 5 3 , 7 5}$ & $\mathbf{5 8 , 1 5}$ \\
\hline
\end{tabular}

Sumber: Pengamatan lapangan, 2018.

Hasil pengamatan berat segar yang telah di rata-ratakan seperti ditunjukkan dalam Tabel 4, selanjutnya dianalisis dengan analisis ragam seperti dalam Tabel 5 .

Tabel 5. Analisis ragam berat segar

\begin{tabular}{lcccccc}
\hline \multirow{2}{*}{ SK } & \multirow{2}{*}{ DB } & \multirow{2}{*}{ JK } & \multirow{2}{*}{ KT } & \multirow{2}{*}{ Fhitung } & \multicolumn{2}{c}{ Ftabel } \\
\cline { 6 - 7 } Ulangan & 4 & 11,00 & 2,75 & $0,16^{\text {tn }}$ & 3,01 & 4,77 \\
Perlakuan & 3 & 3908,50 & 977,13 & $56,29^{* *}$ & 3,01 & 4,77 \\
Galat & 16 & 277,75 & 17,36 & & & \\
\hline Total & $\mathbf{2 4}$ & $\mathbf{4 1 9 7 , 2 5}$ & \multicolumn{3}{c}{ kk $=\mathbf{7 , 1 7 \%}$} \\
\hline
\end{tabular}

Sumber: Analisa data, 2018.

Keterangan: tn = pengaruh tidak nyata pada selang kepercayaan $95 \%$ ** = pengaruh nyata pada selang kepercayaan $99 \%$

$\begin{array}{llll}\text { Hasil analisis data seperti } & \text { segar. Langkah selanjutnya } \\ \text { pada Tabel } 5 \text { diketahui bahwa } & \text { dilakukan uji BNJ yang hasil } \\ \text { perlakuan Bokashi Kulit Rambutan } & \text { perhitungannya ditampilkan dalam } \\ \text { berpengaruh nyata terhadap berat } & \text { Tabel 6. }\end{array}$

Tabel 6. Uji BNJ Bokashi Kulit Rambutan Terhadap Berat Segar

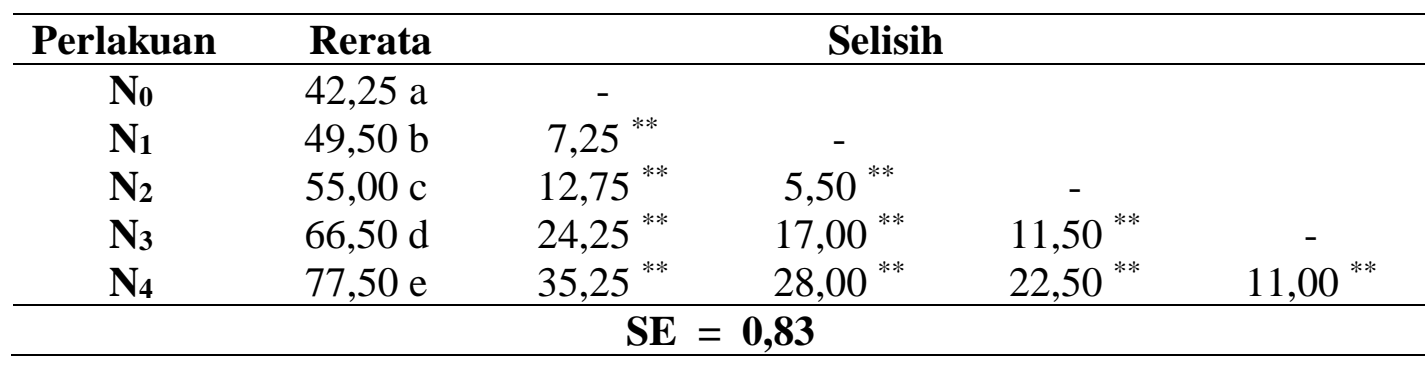


Pemanfaatan Kulit Rambutan Sebagai Bokashi Untuk Meningkatkan Pertumbuhan Dan Hasil Bayam Cabut (Amaranthus Tricolor, L)

$\begin{array}{ll}Q_{0,05}=4,05 & \text { BNJ }_{0,05}=3,37\end{array}$

$Q_{0,01}=\mathbf{5 , 1 9}$

$\mathrm{BNJ}_{0,01}=\mathbf{4 , 3 2}$

Sumber: Analisa data, 2018.

Keterangan: $* *=$ pengaruh nyata pada selang kepercayaan $99 \%$

Hasil uji BNJ seperti yang terlihat dalam Tabel 6 diketahui bahwa nilai selisih rata-rata berat segar mengikuti taraf pemberian bokashi kulit rambutan. Semakin tinggi taraf pemberian bokashi kulit rambutan beda berat segar per tanaman juga tinggi.

\section{Pembahasan}

Hasil penelitian diketahui bahwa pertumbuhan dan hasil tanaman bayam cabut yang ditandai dengan tinggi tnaman, jumlah daun, dan berat segar mengikuti taraf pemberian bokashi kulit rambutan. Semakin tinggi taraf pemberian bokashi kulit rambutan tinggi tanaman, jumlah daun, dan berat segar juga semakin tinggi.

Hal ini membuktikan bahwa bokashi kulit rambutan dapat menambah bahan organik tanah, sehingga kondisi tanah menjadi baik seperti tekstur maupun strukturnya. Harjadi (1991:175) menyatakan bahwa penambahan bahan organik akan meningkatkan kestabilan struktur, tekstur, daya olah, tata air dan udara tanah. Produksi yang dihasilkan oleh tanaman erat hubungannya dengan kesuburan tanaman.

Notohadiprawiro

$(1984: 3)$ mengemukakan bahwa pemberian bahan organik mampu memperbaiki sifat fisik, kimia, serta biologi tanah dengan cara melepaskan ion hara dari unsur yang mengikat mineral tanah. Lepasnya ikatan hara dari partikel tanah menyebabkan unsur hara menjadi tersedia bagi tanaman sehingga unsur-unsur hara tersebut berperan penting dalam memacu pembentukan sel, pepanjangan, maupun jumlah sel baru.

Hasil uji analisa data diketahui bahwa pemberian $2 \mathrm{~kg}$ bokashi kulit rambutan menghasilkan tinggi tanaman dan berat segar ratarata tertinggi, hal ini diduga karena dengan pemberian $2 \mathrm{~kg}$ menyebabkan bahan organik bertambah sehingga menyebabkan 
tanah menjadi remah dan membuat perkembangan akar menjadi baik yang pada akhirnya memudahkan rambutrambut akar menyerap garamgaram mineral dalam tanah. Menurut Lakitan (1996:204), akar mampu berkembang dalam merespons terhadap distribusi hara dan air tanah. Akar mengalami perkembangan dengan tumbuhnya akar-akar lateral secara intensif pada daerah yang kaya akan hara.

Perkembangan akar tanaman yang baik menyebabkan tanaman dapat menyerap unsur hara dengan baik, seperti $\mathrm{N}, \mathrm{P}$, dan $\mathrm{K}$ sehingga menyebabkan pembelahan sel dalam tanaman juga baik. Harjadi (1991:103) menyatakan pembentukan sel pada tanaman diperlukan karbohidrat dalam jumlah yang besar, karena dinding-dindingnya terbuat dari selulosa dan protoplasma yang kebanyakan terbuat dari gula, sehingga bila faktor-faktor lain mendukung maka laju pembelahan sel menjadi optimal.

\section{KESIMPULAN DAN SARAN}

\section{Kesimpulan}

Hasil analisa data pada penelitian ini diambil kesimpulan sebagai berikut:

1. Bokashi kulit rambutan berpengaruh terhadap partumbuhan dan hasil tanaman bayam cabut.

2. Dosis pemberian bokashi kulit rambutan $2 \mathrm{~kg} / \mathrm{m}^{2}$ menghasilkan pertumbuhan dan hasil bayam cabut tertinggi. Rata-rata tinggi tanaman 23,40 cm dan berat segar rata-rata 77,50 gram per tanaman.

\section{Saran}

Berdasarkan hasil penelitian, disarankan sebagai berikut:

1. Bokashi kulit rambutan dapat diberikan pada tanah yang kurang subur karena mampu meningkatkan pertumbuhan dan hasil bayam cabut.

2. Dosis bokashi kulit rambutan yang dianjurkan untuk meningkatkan pertumbuhan dan hasil bayam cabut yaitu $2 \mathrm{~kg} / \mathrm{m}^{2}$.

3. Untuk penelitian selanjutnya, dosisi pemberian bokashi kulit rambutan dapat ditingkatkan. 


\section{DAFTAR PUSTAKA}

Badan Pusat Statistik Kalimantan Barat. 2015. Kalimantan Barat Dalam Angka. Badan Pusat Statistik Kalimantan Barat. Pontianak.

Bandini, Y dan Nurudin Azis. 2005. Bayam. Penebar Swadaya. Jakarta.

Dewi, SS, Bambang H.I, Dewi P. 2005. Pengaruh Macam Pupuk Organik Terhadap Pertumbuhan dan Hasil Jagung Manis (Zea mayssaccharata, Sturt). Jurnal Agrosains. Vol 1 No 1 ISSN 0216-499X.

Gaspersz, V., 1994. Metode Perancangan Percobaan. Armico. Bandung.

Hakim N., Y.M. Nyakpa, A.M. Lubis, S.G. Nugroho, M.R. Saul, M.A. Diha, G.B. Hong, dan E.D. Bailey. 1986. Dasar-dasar Ilmu Tanah. Universitas Lampung Press. Lampung.

Hardjowigeno, S. 2003. Ilmu Tanah. Akademika Pressindo. Jakarta.

Harjadi, S.S. 1991. Pengantar Agronomi. Gramedia. Jakarta.

Lakitan, Benyamin. 1996. DasarDasar Fisiologi Tumbuhan. Jakarta: PT. Radja Grafindo Persada.
Murbandono, L. 2006. Membuat Kompos. Penebar swadaya. Jakarta.

Notohadiprawiro,
Pengelolaan
Tanah dan Pesuburan
Efisiensi Pemupukan. Jurusan
Tanah. Fakultas Pertanian.
Universitas Gadjah Mada.

Notohadiprawiro, T. 1986. Ultisol, Fakta dan Implementasi Pertaniannya. Buletin Pusat Penelitian Marihat No. 6. Tahun 1986. Repro: Ilmu Tanah Universitas Gajah Mada. Yogyakarta.

Redaksi AgroMedia, 2007. Cara Praktik Membuat Kompos. AgroMedia Pustaka. Jakarta.

Rosmarkam, A. dan Yuwono, N.W. 2002. Ilmu Kesuburan Tanah. Kanisius. Yogyakarta.

Salisbury, F. B. dan C. W. Ross. 1995. Fisiologi Tumbuhan. Jilid I. Edisi IV. ITB, Bandung.

Setyamidjaja, D., 1986. Pupuk dan Pemupukan. Simplex. Jakarta.

Sunarjono, H. 2003. Bertanam 30 jenis sayur. Penebar Swadaya. Jakarta

Sutanto, R. 2006. Pertanian Organik. Kanisius. Yogyakarta. 